\title{
SELECTIVITY OF THE HERBICIDE CHLORIMURON ETHYL ON YOUNG COFFEE PLANTS
}

\author{
Dalyse Toledo Castanheira ${ }^{1}$, Giovani Belutti Voltolini ${ }^{2}$, Ademilson de Oliveira Alecrim ${ }^{3}$, \\ Tiago Teruel Rezende ${ }^{4}$, Pedro Menicucci Netto ${ }^{5}$, Larissa Cocato da Silva ${ }^{6}$, \\ Rubens José Guimarães ${ }^{7}$
}

(Received: September 12, 2019; accepted: October 23, 2019)

\begin{abstract}
The great interference of weeds in coffee plants, due to competition for water, light and nutrients, makes their control essential. Among these control methods, the chemical stands out, due to its high efficiency and low cost. However, as a function of application failures, phytotoxicity is frequent in coffee plants due to herbicide drift. Aiming to search for active ingredients selective to coffee, the objective of this study was to evaluate the selectivity of the active ingredient Chlorimuron ethyl in coffee seedlings, and its effects on plant morphology, anatomy and physiology. The experiment was carried out in a greenhouse with 'Topázio MG 1190' coffee plants (Coffea arabica L.), grown in 11-L pots. The statistical design was in randomized blocks, with four replicates and four herbicide doses. Each plot consisted of three plants. The treatments were: $0 \%$; $50 \% ; 100 \%$ and $200 \%$ of the recommended commercial dose of the herbicide Chlorimuron ethyl. Evaluations were performed at 120 days after treatment application. Morphological, physiological and anatomical characteristics were evaluated, besides possible phytotoxicity symptoms inherent to herbicide application. The herbicide Chlorimuron ethyl caused phytotoxicity symptoms in coffee seedlings, evidenced from the leaflet dose, through leaf deformation and cracking, with growth losses not exceeding $10 \%$, but without damage to plant physiology and anatomy.
\end{abstract}

Index terms: Coffea arabica, drift, phytotoxicity.

\section{INTRODUCTION}

The coffee agribusiness is responsible for generating income and jobs in Brazil and, according to Conab (2019), the expected Brazilian production for 2019 will be around 50 million 60$\mathrm{kg}$ processed bags. Coffee crop yield is directly related to several factors, such as soil fertility, plant nutrition, phytosanitary control, application technologies, climatic conditions and weed management (OLIVEIRA, 2013).

Weed management contributes to the success in production, as competition occurs in relation to the essential resources for crop development such as water, light, space and nutrients (FIALHO, 2011; LORENZI, 2014).

Among the weed control methods, chemical control stands out due to its advantages over the others. However, there are still few coffeeselective herbicides that have been registered for the crop, leaving the option of using non-selective herbicides in a directed jet, which increases the application cost and the possibility of drift, causing injuries to the plants (SILVA et al.; 2017).

The herbicide Chlorimuron ethyl is widely used in agriculture has a systemic action, acting selectively for the control of eudicotyledons. It is absorbed exclusively via leaf and has translocation throughout the plant, being very efficient for the control of Bidens pilosa, Acanthospermum hispidum, Alternanthera tenella, Amaranthus viridis, and Ipomoea sp. (RODRIGUES; ALMEIDA, 2018; LORENZI, 2014).

There are few selective herbicides recommended for coffee plants and, in many instances, the adoption of non-selective herbicides implies plant injury due to phytotoxicity effects (LORENZI, 2014). Above all, this damage occurs due to incorrect application technologies and, consequently, the presence of drift at the time of application (GANDOLFO, 2014).

Aiming at the search for active ingredients selective to coffee for weed control, the objective of this study was to evaluate the selectivity of the herbicide Clorimuron ethyl in young coffee plants and its influence on plant morphology and physiology.

\section{MATERIAL AND METHODS}

The experiment was carried out in a greenhouse in the municipality of Lavras-MG, located in the Southern Region of the Minas

\footnotetext{
${ }^{1}$ Universidade Federal de Viçosa/UFV - Departamento de Fitotecnia/DFT - Avenida Peter Henry Rolfs, s/n - Campus Universitário 36.570-900 - Viçosa - MG - dalysecastanheira@hotmail.com

2,3,5,6,7Universidade Federal de Lavras/UFLA - Departamento de Agricultura/DAG - Cx. P. 3037 - 37.200-000 - Lavras MG giovanibelutti77@hotmail.com, ademilsonagronomia@gmail.com, pedromenicucci2010@hotmail.com, larissa.cocato@rehagro.com.br, rubensjg@dag.ufla.br

${ }^{4}$ Universidade José do Rosário Vellano - Rodovia MG 179, Km 0 - Campus Universitário - 37.152-440 - Alfenas - MG tiago.rezende@unifenas.br
} 
Gerais State, at an altitude of $918 \mathrm{~m}, 21^{\circ} 14^{\prime} \mathrm{S}$ latitude and $45^{\circ} 00^{\prime} \mathrm{W}$ longitude, from December 2016 to March 2017. The annual average air temperature is $19.4{ }^{\circ} \mathrm{C}$, with a maximum of 26.1 ${ }^{\circ} \mathrm{C}$ and the minimum, $14.4{ }^{\circ} \mathrm{C}$.

For the simulation of intoxication, 'Topázio MG1190' coffee (Coffea arabica L.) seedlings were planted in 11-L pots, with 4-5 pairs of leaves. A randomized block design with four replicates and four doses of the herbicide Clorimuron ethyl was used: $0 \% ; 50 \% ; 100 \%$ and $200 \%$ of the recommended commercial dose $\left(80\right.$ g.ha $\left.{ }^{-1}\right)$ applied directly to coffee plants. Each plot consisted of three plants.

The application of the herbicide at different doses was carried out using a $\mathrm{CO}_{2}$ pressurized costal sprayer, with pressure of 45 pounds, and the spray bar directed close to the top of the plants, with a spray volume of 300 L.ha $^{-1}$. After the application, the plants remained in the greenhouse for 120 days, daily irrigated, aiming at the maintenance of field capacity $(100 \%)$. The management and cultural treatment were carried out as recommended by Matiello (2010).

Visual observation and imaging of the symptoms caused by the action of the herbicide were performed daily. The anatomical and physiological evaluations of the plants were performed at the end of the experiment. The following growth characteristics were evaluated: plant height, measured in centimeters from the neck to the terminal bud of the orthotropic branch of plants; number of leaves; stem diameter, measured in millimeters at the collar of the plants; number of plagiotropic branches; leaf area, in $\mathrm{cm}^{2}$, quantified by leaf discs (Cunha et al., 2010); shoot, root, plagiotropic branches, ortotropic branche and leaf dry matter, in grams. Root length analysis, in centimeters, was also determined by the sum of the linear extension of each fragment of the root system and the mean root diameter, in centimeters, both using the imaging software Safira (JORGE; SILVA, 2010).

For the evaluation of leaf anatomy, at 104 days, leaves located between the second and third node of the plagiotropic branch of the plants were collected. Subsequently, in the laboratory, the paradermic and transverse sections were performed. Those paradermic were obtained before of collection, using the universal instant adhesive (cyanoacrylate ester) method (SEGATTO et al., 2004). In order to obtain the cross sections, the plant material underwent dehydration in an ethylic series, and then immersed in methacrylate (methodology according to the manufacturer) and sectioned with $0.8 \mu \mathrm{m}$ thickness using a rotary microtome. Subsequently, these were stained with toluidine blue (O'brien; Feder; Mccully, 1964) and the blades were assembled using Entelan ${ }^{\circledR}$ as a medium. The slides of both sections (paradermic and transverse) were observed and photographed under an optical microscope coupled to a digital camera. The images obtained were analyzed in the UTHSCSA-Imagetool program and then the stomatal characteristics, leaf tissues and vascular bundles were evaluated. For the stomatal characterization, the following characteristics were evaluated: stomatal number; polar diameter of the stomata and equatorial diameter of the stomata. Stomatal density (number of stomata per $\mathrm{mm}^{2}$ ) and the polar diameter/equatorial diameters stomatal ratio, which is highly correlated with stomatal functionality (Silva, et al., 2014), was calculated using these data. To evaluate leaf tissues, the following were measured: epidermal thickness of the adaxial face; thickness of the palisade parenchyma; thickness of the spongy parenchyma; and thickness of the mesophyll. In the evaluation of vascular bundles, the following parameters were measured: thickness of the phloem region; diameter of xylem vessels; and number of xylem vessels.

For the physiological analyses, a portable infrared gas analysis system (LICOR - 6400XT) was used to evaluate the net photosynthetic rate $\left(\mathrm{A}-\mu \mathrm{mol} \mathrm{CO} 2 \mathrm{~m}^{-2} \mathrm{~s}^{-1}\right.$ ), stomatal conductance (gs $\left.\mathrm{mol} \mathrm{H} 2 \mathrm{O} \mathrm{m}^{-2} \mathrm{~s}^{-1}\right)$, and transpiration rate $(\mathrm{E}-\mathrm{mmol}$ $\mathrm{m}^{-2} \mathrm{~s}^{-1}$ ). The water use efficiency (EiUA - $\mu \mathrm{mol}$ $\mathrm{CO}_{2} \mathrm{mmol}^{-1} \mathrm{H} 2 \mathrm{O}$ ), calculated by the $\mathrm{A} / \mathrm{E}$ ratio (Yan et al., 2015), was also evaluated. The evaluations were performed between 9 and 11 o'clock in the morning under artificial light $\left(1000 \mu \mathrm{mol} \mathrm{m}^{-2} \mathrm{~s}^{-1}\right)$, using leaves located between the second and third node of the plagiotropic branch of the plants.

For data analysis, the SISVAR Statistical Software was used (Ferreira, 2011).

\section{RESULTS AND DISCUSSION}

Observing the obtained images, mild phytotoxicity symptoms were viewed in coffee seedlings as a function of the simulated drift of herbicide Chlorimuron ethyl during the 120 days of evaluation. In some plants, symptoms such as cracking and leaf deformation could be noted, especially in the growing regions (Figure 1). 


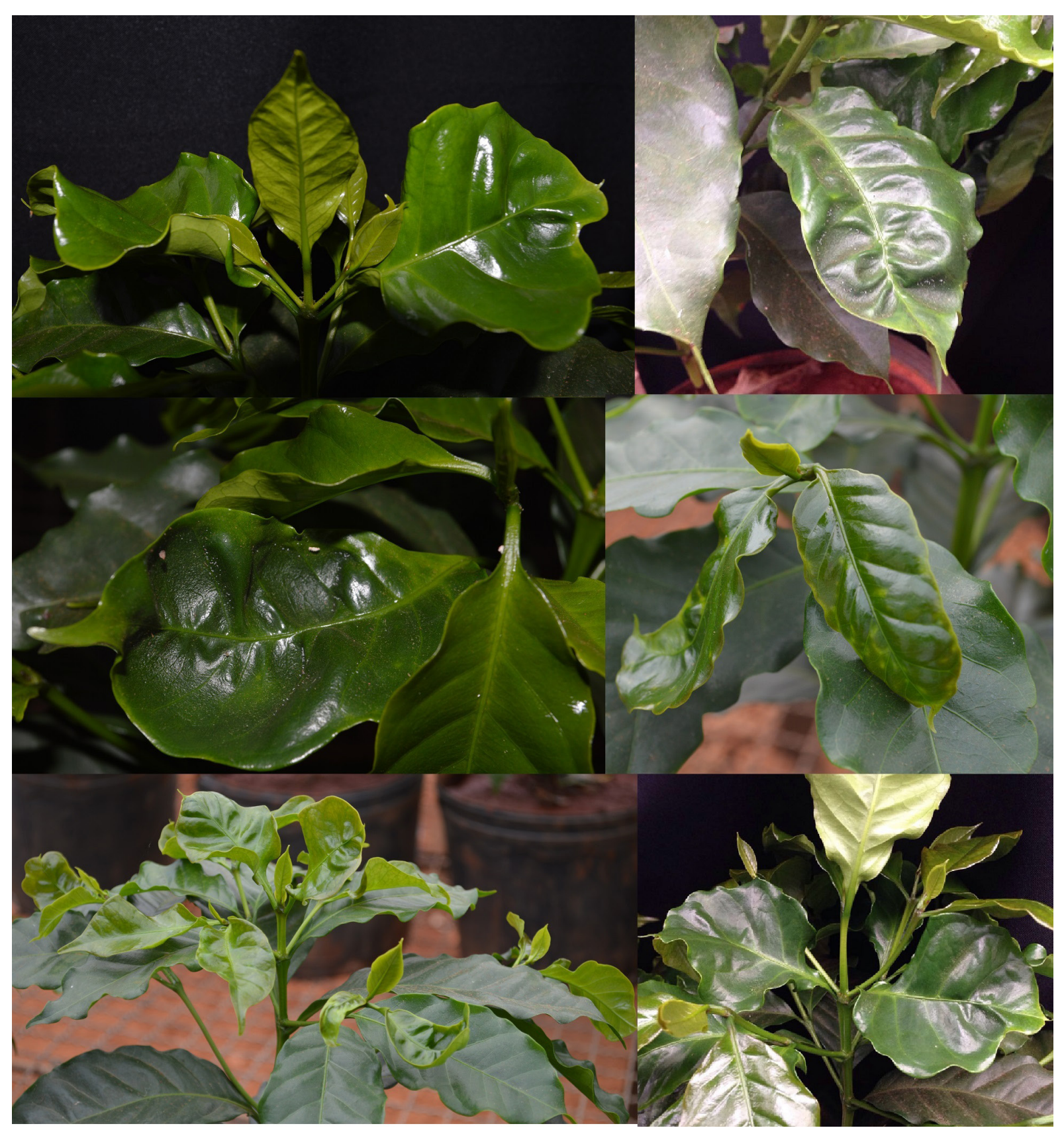

FIGURE 1 - Leaf cracking and deformation in growing regions of coffee submitted to the simulated drift of herbicide Chlorimuron ethyl 10 days after application.

The inhibition of plant metabolism as a function of the application of this herbicide is known to prevent amino acid formation, reducing plant growth (RODRIGUES; ALMEIDA, 2018). However, some studies using Chlorimuron ethyl show herbicide selectivity to crop and no phytotoxicity up to 37.5 g.ia.ha $^{-1}$ (ANZALONE, 2014). Furthermore, it is emphasized that this dose represents the commercial dose of the herbicide plus $25 \%$. In this work, the cultivar used was Catuaí (Coffea arabica). In this sense, França et al. (2013) found that coffee cultivars can be differently affected with the same herbicide drift, so that Catucaí cultivar is more tolerant to glyphosate herbicide than Acaiá cultivar.

In this study, high doses of Chlorimuron ethyl were used to elucidate its interaction with coffee and to verify the possibility of its use as a 
selective herbicide to coffee plants. The observed symptoms may be associated only with overdoses studied in this paper.

For stem diameter, number of plagiotropic branches, number of leaves, root system dry weight, photosynthetic rate, transpiratory rate, stomatal conductance, water use efficiency, root volume, root surface area, root diameter, total root length, stomatal number, stomatal polar diameter, stomatal equatorial diameter, stomatal functionality, stomatal density, adaxial epidermis thickness, palisade parenchyma thickness, spongy parenchyma thickness, abaxial epidermis thickness and mesophyll thickness, there was no significant effect of the treatments. However, for height, length of plagiotropic branches, weight of the orthotropic branch, weight of plagiotropic branches, leaf weight, and leaf area, there was a significant effect as a function of the source of variation of simulated drift herbicide doses (Figure 2).
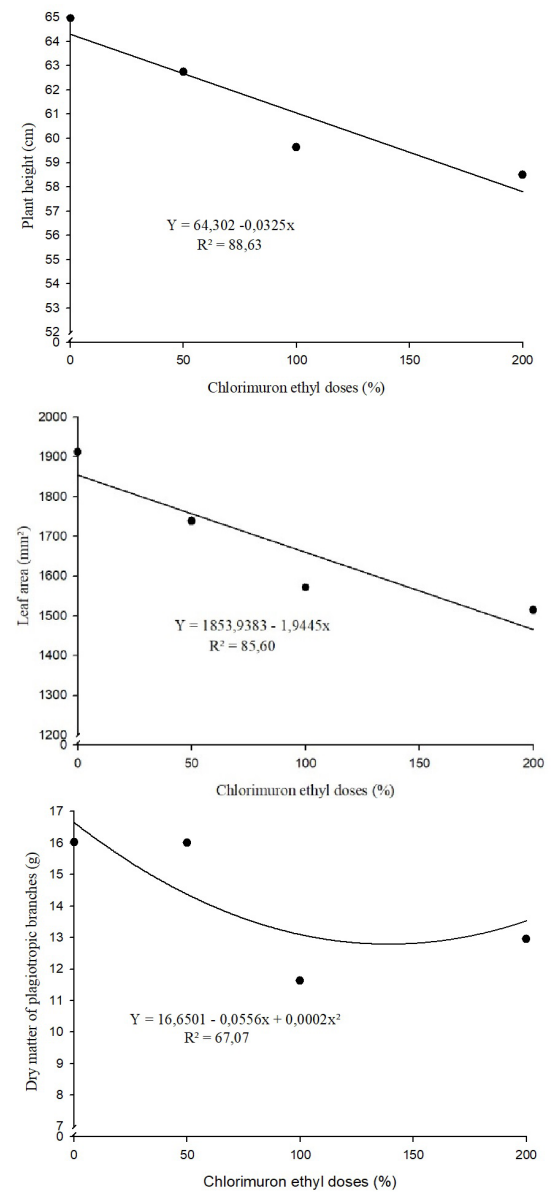

It can be seen from Figure 2 that the characteristics of height, length of plagiotropic branches, weight of plagiotropic branches, leaf weight and leaf area were negatively affected in response to herbicide doses that simulated drift in the field, so that linear decreases occurred as the herbicide doses (drift) increased up to $200 \%$. For the variable weight of plagiotropic branches, there was a quadratic effect, with decreases as the herbicide dose increased to a minimum of $139 \%$.

Phytotoxicity symptoms in plants appeared from drift simulation at the manufacturer's recommended dose ( 80 g.ha $\left.^{-1}\right)$ for weed control, with losses of $5.06 \%$ in height, $7.41 \%$ in length of plagiotropic branches, $9.66 \%$ in the weight of plagiotropic branches, $1.2 \%$ in leaf weight and $10.5 \%$ in leaf area. In the drift simulation with double the dose recommended by the manufacturer for weed control, the symptoms were more intense, causing losses of approximately $20 \%$ in the weight of plagiotropic branches.
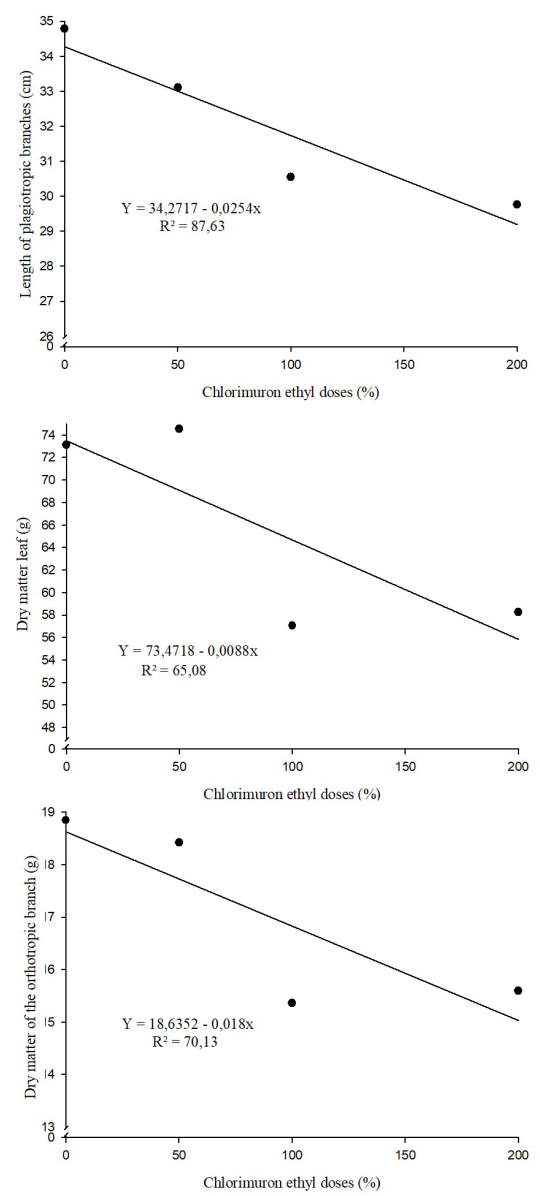

FIGURE 2 - (A) - Height (cm), (B) - length of plagiotropic branches (cm), (C) - weight of plagiotropic branches (g), (D) - weight of the orthotropic branch (g), (E) - leaf weight (g) and (F) - leaf area $\left(\mathrm{cm}^{2}\right)$ of coffee plants subjected to the application of the herbicide Chlorimuron ethyl. 
Anzalone et al. (2014) used ALSinhibiting herbicides, and observed cases of mild phytotoxicity in coffee plants when subjected to simulated drift of the herbicide Metsulfuron methyl.

Also studying ALS inhibitors, from the sulfonylurea group, Alcântara et al. (2000) found a reduction in plant size above $20 \%$ with the use of the simulated drift of herbicide Nicosulfuron. In the same study, they also verified moderate selectivity of the herbicide Halosulfuron to coffee seedlings, causing mild phytotoxicity symptoms.

Ronchi \& Silva (2003) evaluated the herbicide Flazasulfuron, and observed phytotoxicity symptoms inherent to the application of this herbicide close to $40 \%$, but without damage to plant height. The same herbicide was also tested for weed control in coffee and bean intercropping, where it was excellent for bean control (desiccation) and with about $10 \%$ phytotoxicity to the coffee crop (Ronchi \& Silva, 2004).

Allied to this, Carvalho et al. (2014) evaluated the effect of herbicide application on coffee plants, with and without the presence of mycorrhizae, and verified phytotoxicity effects inherent to the application of the herbicide Chlorimuron ethyl in the package leaflet, but with improvements in the presence of mycorrhizal plants.

Although it is systemic and has mobility in the phloem, this herbicide did not affect the root system of coffee plants. This can be explained by the crop tolerance mechanism, where it may have been converted to inactive compounds, so that only a small part of plant metabolism is inhibited (RODRIGUES; ALMEIDA, 2018). It is suggested that leaf physiology and anatomy were not affected for the same reason.

Thus, the losses caused by the application of Chlorimuron ethyl in the coffee crop only occur under drift conditions similar to the dose recommended by the manufacturer for weed control, or drifts similar to the overdose of this herbicide. However, the application of this herbicide with correct application technologies ensures weed control without harming the coffee plant.

\section{CONCLUSIONS}

The herbicide Chlorimuron ethyl showed plant phytotoxicity symptoms in coffee, when the drift simulation was equal to or greater than the leaflet dose, through leaf deformations and cracking, with growth losses not exceeding $10 \%$, but without damage to plant physiology and anatomy.

The application of Chlorimuron ethyl for weed control in coffee is selective, as long as no equal or higher doses of herbicide are directly applied to them.

\section{ACKNOWLEDGEMENTS}

The authors would like to thank CAPES, FAPEMIG, CNPq and EMBRAPA, for supporting this study.

\section{REFERENCES}

ALCÂNTARA, E. N. Avaliação de herbicidas para cafeeiros em formação. In: SIMPÓSIO DE PESQUISA DOS CAFÉS DO BRASIL, 1., 2000, Poços de Caldas. Resumos Expandidos... Brasília, DF: Embrapa Café, 2000. p. 967-970.

ANZALONE, A.; et al. Respuesta del cafeto (Coffea arabica) Catuaí a los herbicidas glifosato, clomazone, linuron, 2,4-D, metsulfuron-metil, rimsulfuron y clorimuron-etil. Bioagro. Barquisimeto, v. 26, n. 1, p. 3-12, abr, 2014.

CARVALHO, F, P. et al. Sensibilidade de plantas de café micorrizadas à herbicidas. Revista Brasileira de Herbicidas, v.13, n. 2, p. 134-142, 2014.

CONAB. $2^{\circ}$ levantamento da safra de café 2018/ 2019. Brasília, 2019. Disponível em: https://www. conab.gov.br/info-agro/safras/cafe Acesso em: set. 2019.

CUNHA, J. L. X. L.; et al. Comparação de métodos de área foliar em Chrysobalanus icaco L. Agropecuária Científica no Semiárido, Patos, v. 6, n. 3, p. 22-27, jul./set. 2010.

EUROPEAN WEED RESEARCH COUNCIL (EWRC). Report of the $3^{\text {rd }}$ and $4^{\text {th }}$ meetings of EWRC. Committee of methods in weed research. Weed Research, Oxford, v. 4, p. 88, 1964.

FERREIRA, D. F. Sisvar: a computer statistical analysis system. Ciência e Agrotecnologia (UFLA), Lavras, v. 35, n. 6, p. 1039-1042, 2011.

FIALHO, C. M. T.; et al. Interferência de plantas daninhas sobre o crescimento inicial de Coffea arabica L. Planta Daninha, Viçosa, v.29, n.1, p. 137-147, 2011. 
FRANCA, A.C. et al. Deriva simulada do glyphosate em cultivares de café Acaiá e Catucaí. Planta daninha, Viçosa, v. 31, n. 2, p. 443-451, 2013.

GANDOLFO, M. A.; et al. Effect of working pressure at different spray nozzles on drift quantification in wind tunnel. Engenharia Agrícola, Jaboticabal, v. 34, n. 1, p. 66-73, Jan/Fev 2014.

JORGE, L. A. C.; SILVA, D. J. C. B. SAFIRA: Manual de utilização. São Carlos: Embrapa CPDIA, 2010. 29p.

LORENZI, H. Manual de Identificação e controle de plantas daninhas. $7^{\mathrm{a}} \mathrm{Ed}$. Nova Odessa - SP. Instituto Plantarum, 2014. 384p.

MATIELlO, J. B. et al. Cultura de Café no Brasil: manual de recomendações. Rio de Janeiro: MAPA/ PROCAFE, 2010. 542 p.

O'BRIEN, T. P.; FEDER, N.; McCULlY, E. Polychromatic staining of plant cell walls by toluidine blue O. Protoplasma, Cambridge, v. 59, n. 2, p. 368373, 1964.

OLIVEIRA, C. M.; et al. Economic impact of exotic insect pests in Brazilian agriculture. Journal of Applied Entomology, Berlin, v. 137, n. 1-2, p. 1-15, 2013.

RODRIGUES, B. N.; ALMEIDA, F. S. Guia de herbicidas. $7^{\mathrm{a}}$ ed., Londrina, 2018. 697p.
RONCHI, C. P.; SILVA, A. A. Tolerância de mudas de café a herbicidas aplicados em pós-emergência. Planta Daninha, Viçosa, v. 21, n. 3, p. 421-426, 2003.

RONCHI, C. P.; SILVA, A. A. Weed control in young coffee plantations through post-emergence herbicide application onto total area. Planta Daninha, Viçosa, v. 22, n. 4, p. 607-615, 2004.

SÁ JÚNIOR, A.; CARVAlHO, L. G.; SILVA, F. F.; ALVES, M. C. Application of the Koppen classification for climatic zoning in the Minas Gerais State, Brazil. Theoretical and Applied Climatology, Viena, v. 108, n. 1, p. 1-7, Apr. 2012.

SEGATTO, F. B.; et al. Técnica para o estudo da anatomia da epiderme foliar de batata. Ciência Rural, Santa Maria, v.34, n.5, p.1597-1601, 2004.

SILVA, H., et al. Relationships between leaf anatomy, morphology, and water use efficiency in Aloe vera (L) Burm f. as a function of water availability. Revista chilena de história natural, Santiago, v. 87, n. 1, p. 13,2014 .

SILVA, L. G., et al. Sintomas de fitotoxicidade e crescimento de mudas de café submetidas aos herbicidas inibidores da PROTOX. Coffee Science, Lavras, v.12, n.3, 2017

YAN, J., et al. High photosynthetic rate and water use efficiency of Miscanthus lutarioriparius characterize an energy crop in the semiarid temperate region. Gcb Bioenergy, New Jersey, v. 7, n. 2, p. 207-218, 2015. 